\title{
ISOLATION OF AMOEBAE FROM THE AIR
}

\author{
D. Kingston * AND D. C. WarhuRst $\dagger$ \\ Cross-Infection Reference Laboratory, Central Public Health Laboratory, Colindale Avenue, \\ London, and Department of Parasitology, National Institute for Medical Research, Mill \\ Hill, London
}

DURING an investigation into the possibility of isolating respiratory syncytial virus from the environment (Kingston, 1969), hartmannellid amoebae were isolated from the air and from the surfaces in cubicles in which infants with acute bronchiolitis were being nursed. In the present study a more extensive investigation was carried out, partly because of the possibility that these amoebae may be associated with disease.

\section{METHODS \\ Isolation of the amoebae}

Tissue culture method. Standard virus cultivation techniques were used. In outline, the method was to suck air into the liquid contained in a special modification of the slit sampler (Lidwell, 1966) and then to inoculate as much as possible of the liquid on to HeLa cells. The cells were maintained on Gey's solution with 5 per cent. rabbit serum, $0 \cdot 25$ per cent. lactalbumin hydrolysate, and with 100 units each of penicillin and streptomycin and $5 \mu \mathrm{g}$ Fungizone per $\mathrm{ml}$. The cells were incubated at $33^{\circ}-37^{\circ} \mathrm{C}$, mean $c .35^{\circ} \mathrm{C}$. This technique was used because virus isolation was the original object of the work. This approach has the disadvantage of being laborious, of requiring the cell sheet to be washed after an initial short period of incubation to prevent bacteria and fungi breaking through the antibiotic cover, with the risk of losing amoebae, and of requiring the use of a fungistatic agent, that used being Fungizone, which is toxic to some amoebae (personal communication from Dr C. G. Culbertson).

Agar plate method. This method is based on that used by Singh (1952) for cultivation of small free-living amoebae from the soil. Oxoid Ionagar no. 2 was dissolved in glassdistilled water to give 1.5 per cent. water agar, which was poured into $5 \frac{1}{2}$ in. $(14 \mathrm{~cm})$ diameter petri dishes. When set, the plates were dried in the hot room for about $1 \mathrm{hr}$. Klebsiella aerogenes (NCTC9667) was inoculated into a 100-ml bottle of Oxoid nutrient broth no. 2, and after overnight incubation at $37^{\circ} \mathrm{C}$ the bacteria were harvested by centrifugation and resuspended in about $20 \mathrm{ml}$ sterile distilled water. Three millilitres of this suspension was spread on to each water agar plate and allowed to adsorb. The plates were then used for air sampling either by exposing them for $10 \mathrm{~min}$. in a $20 \mathrm{cu}$. $\mathrm{ft}$ ( 570 litre) per min. slit sampler or by leaving them open to the air for various periods up to $7 \mathrm{hr}$ (" settle plates "). Unless otherwise stated, exposure was by the slit-sampler technique. In some preliminary experiments, not reported here, the klebsiella suspension was killed by heating for $2 \mathrm{hr}$ at $56^{\circ} \mathrm{C}$ before being spread on to the plates, but this treatment was discontinued as heat-killed bacteria will not support the growth of some amoebae. The plates were incubated at $30^{\circ}$

Received 27 May 1968; accepted 2 Aug. 1968.

* Present address: MRC Rheumatism Research Unit, Canadian Red Cross Memorial Hospital, Taplow, Maidenhead, Berkshire.

$\dagger$ Present address: Department of Parasitology, Liverpool School of Tropical Medicine, Pembroke Place, Liverpool 3.

J. MED. MICROBIOL.-VOL. 2 (1969) 
or $33^{\circ} \mathrm{C}$ in a moist atmosphere for at least 1 wk unless there was danger of overgrowth. At first the plates were incubated at $37^{\circ} \mathrm{C}$, but an experiment described below showed that more isolations were made at the lower temperatures. The amoebae grew as zones of clearing, with a line of amoebae at the advancing edge and encysted forms at the centre. These zones were similar to those caused by myxobacteria and myxomycetes. The former organisms, however, do not show any amoebae at the advancing edge, and after prolonged incubation produce yellowish fruiting bodies. Myxomycetes soon develop the characteristic syncytial form with protoplasmic streaming. A magnification of $\times 50$ was found suitable for detailed examination of the plates. Some fungal growth always appeared, which gave trouble in the purification of the amoebic cultures. The very small colonies of bacteria that developed did not interfere with purification. The bacterial lawn on water agar can, in general, be recommended as a selective medium for the amoebae.

\section{Identification of the amoebae}

The colonies of amoebae were subcultured on to non-nutrient agar plates prepared as described and spread with $K$. aerogenes. After $2-4$ days at room temperature $\left(21^{\circ} \mathrm{C}\right)$ in a moist atmosphere, the plates showing amoebic growth were flooded with sterile distilled water. An identification was made by microscopic examination of the living organisms, which were observed in situ on the plates, and also in drops of the suspension, at intervals for $48 \mathrm{hr}$. The major characters used to identify the amoebae were the movement and form of the trophozoites, the presence or absence of a contractile vacuole, the form of the cysts, and the production and morphology of the flagellated forms. The following key was used.

(1) (a) Flagellates produced:-Family Schizopyrenidae Singh 1952 . . . . (6)

(b) Flagellates not produced. . . . . . . . . . . . (2)

(2) (a) Elongated, slightly motile stick-like forms produced, which have no contractile vacuole. Cysts double walled. Amoebae when rounded are 10-20 $\mu \mathrm{m}$ in diameter. Family Hartmannellidae Singh 1952. Hartmannella leptocnemus Singh 1952.

(b) Limax forms produced (rapidly moving elongated forms with anterior blunt pseudopodium; contractile vacuole present). Family Schizopyrenidae Singh 1952. Genus Schizopyrenus Singh 1952.

(c) Little change in trophozoites. Encystment generally occurs. Family Hartmannellidae Singh 1952.

(3) (a) Contractile vacuole present. Trophozoites generally more than $20 \mu \mathrm{m}$ in diameter when rounded.

(b) Contractile vacuole not present. Trophozoites when rounded 10-20 $\mu \mathrm{m}$ or less in diameter. Cyst smooth surfaced, single walled. Hartmannella agricola Goodey 1916.

(4) (a) Mature cyst smooth surfaced, single walled; no ostioles. Hartmannella glebae Dobell 1914.

(b) Mature cyst angular, double walled, with ostioles closed by opercula at the angles. Trophozoite has small spike-like pseudopodia. Genus Hartmannella: subgenus Acanthamoeba.

(5) (a) Trophozoite generally $10-30 \mu \mathrm{m}$ diameter. Cyst spherical. H.(Acanthamoeba) castellanii Douglas 1930.

(b) Trophozoite generally more than $30 \mu \mathrm{m}$ in diameter. Cyst biconvex. H.(Acanthamoeba) astronyxis Ray and Hayes 1954.

(6) (a) Flagellates ovoid to pyriform; they have no gullet and do not feed. . . . (7) 1852.

(b) Flagellates often rostrate, have gullet and ingest bacteria. Genus Tetramitus Perty

(7) (a) Flagellate transformation produced in first few hours. Genus Naegleria Schardinger 1899.

(b) A small percentage of amoebae transform into flagellates, but only after $20-48 \mathrm{hr}$ at $21^{\circ} \mathrm{C}$. Genus Didascalus Singh 1952.

Descriptions of $H$. castellanii ( $\equiv H$. rhysodes) are given by Douglas (1930), Volkonsky (1931), Singh (1952), Neff (1957), Adam (1964), Page (1967), Wang and Feldman (1967), and Warhurst and Armstrong (1968), descriptions of $H$. astronyxis by Ray and Hayes (1954), 
and Page, a description of Tetramitus by Bunting (1926), and descriptions of $H$. leptocnemus, Didascalus, Schizopyrenus, Naegleria, $H$. agricola and $H$. glebae by Singh. Figures useful for identification where these papers are not available are given by Kudo (1954).

This key gives a rapid provisional identification of small amoebae and amoeboflagellates. Entamoebae would not have been detected by the culture method used. Study of the mitotic cycles of the amoebae, although extremely time-consuming, is important (Singh; Warhurst and Armstrong), since it provides the major criterion upon which a firm identification may be based. The mitotic cycles of isolates no. 1 and 13 were examined, and the results confirmed the identification as $H$. castellanii and Naegleria according to the key. Difficulty was found in distinguishing between $H$. leptocnemus and $H$. agricola, since most of the amoebae that had the typical elongated and slightly motile body form of $H$. leptocnemus were found to have single-walled cysts, typical of $H$. agricola. These have been designated H. leptocnemus/agricola.

In view of the work of Page, what is termed here the subgenus Acanthamoeba will probably have to be raised to the status of a genus.

\section{Growth in tissue culture}

Amoebae, either from agar plates with $K$. aerogenes or from tissue-culture tubes, were inoculated into stationary tubes containing a monolayer of HeLa cells on coverslips and incubated at $33^{\circ}$ or $37^{\circ} \mathrm{C}$. After up to 6 days the cells were fixed in Carnoy's fluid and stained with haematoxylin and eosin. They were examined for amoebae and for stripping of the cell sheet.

Cultures at $33^{\circ} \mathrm{C}$. In this experiment the cells, which were kindly supplied by $\mathrm{Dr}$ Marguerite S. Pereira, were resuspended in a medium of Gey's solution with 10 per cent. $(\mathrm{v} / \mathrm{v})$ rabbit serum, 0.5 per cent. (w/v) lactalbumin hydrolysate and 100 units each of penicillin and streptomycin per $\mathrm{ml}$, and transferred to tubes containing coverslips. When the cell sheet was confluent, amoebae were inoculated into the tubes, which were then incubated for 2 days. Unfortunately the cell sheet in the control tubes was in poor condition and it was possible to detect only the grosser cytopathic effects.

Cultures at $37^{\circ} \mathrm{C}$. Prepared coverslip cultures were kindly supplied by Dr H. G. Pereira. The cells were grown in Eagle's medium with 10 per cent. (v/v) tryptose phosphate broth, 10 per cent. (v/v) calf serum, 100 units penicillin $\mathrm{G}$ and $100 \mu \mathrm{g}$ streptomycin per $\mathrm{ml}$. In this experiment some of the amoebae were freed from bacteria before they were inoculated into tissue culture (see table I). They were allowed to migrate on agar plates across a lawn of $K$. aerogenes killed by heating at $56^{\circ} \mathrm{C}$ for $2 \mathrm{hr}$, and then cultivated in a modification of Adam's mycological peptone medium (Warhurst and Armstrong). After growth in this medium for $5-7$ days at $36.5^{\circ} \mathrm{C}$, they were concentrated by centrifugation and then inoculated into tissue culture. Cytopathic effects were produced by the bacteria-free amoebae.

\section{RESULTS}

The initial isolations were made by the tissue culture method in Manchester in Dec. 1966 and Jan. 1967. The main investigations, in which the agar plate method was used, were made in the Central Public Health Laboratory, London, in Aug. 1967.

\section{Isolations by the tissue culture method}

The first amoebae were isolated at Booth Hall Children's Hospital, Manchester, in the cubicle occupied by a 10-wk-old infant with an illness diagnosed as acute bronchiolitis. Respiratory syncytial virus was isolated from the throat swab, but no amoebae, and the infant was discharged 3 days after admission. An unidentified cytopathic effect was noticed in the tissue 
cultures inoculated from three air samples, and the causative agent was provisionally identified as the "Ryan agent" (Armstrong and Pereira, 1967; Warhurst and Armstrong) in the Public Health Laboratory, Manchester. Later isolations were made from a floor swab and from a sample of air aspirated through the bedclothes into a raised all-glass impinger (May and Harper, 1957) in a cubicle occupied by another infant with respiratory syncytial virus infection. Amoebae were not isolated from this infant's throat swab. After these isolations, which were made accidentally during attempts to isolate respiratory syncytial virus, deliberate attempts were made to isolate amoebae from the air. At various times four air samples each of $100 \mathrm{cu} . \mathrm{ft}\left(2 \cdot 8 \mathrm{~m}^{3}\right)$ were taken in the corridor near the cubicles where the original isolations had been made and four similar samples were taken in the hospital virus laboratory. Two further samples were taken at the Duchess of York's Hospital, Manchester, one in a ward and one in the garden outside the ward. These samples were processed by Dr J. O'H. Tobin in the Manchester Public Health Laboratory. Amoebae were isolated from only one of the samples, the one taken in the laboratory. In an attempt to encourage the isolation of amoebae, the fluid on the cells was not changed until 2 days after inoculation, instead of after only the 4-5 hr allowed for virus adsorption. Half the cultures inoculated with the first two ward samples and all those inoculated with the second two had to be discarded because of contamination. All further attempts at isolation were therefore made by the agar plate method. One strain of amoeba was examined in detail from each of the three sets of isolations made by the tissue culture method and all were identified as Hartmannella castellanii. The results are given in table I.

\section{Isolations by the agar plate method}

Temperature of incubation. Plates were exposed in pairs, and one plate of each pair was incubated at $37^{\circ} \mathrm{C}$, the other at $30^{\circ} \mathrm{C}$. Of three pairs, one was exposed in a normal laboratory room, one in a special room on the second floor ventilated with outdoor air, and one outside the building. No amoebae were isolated on any of the plates incubated at $37^{\circ} \mathrm{C}$, but one amoeba was isolated from the ventilated room and four amoebae and a myxomycete from the outdoor air on the plates incubated at $30^{\circ} \mathrm{C}$. None was isolated in the laboratory. It was concluded that the lower temperature of incubation gave more isolations and subsequent incubations were carried out at $30^{\circ}$ or $33^{\circ} \mathrm{C}$ according to the availability of incubator space.

Experiments to exclude contamination. It was important, before recording the isolations as being from the air, to exclude the possibility that the amoebae had been deposited on the plates as contaminants during manipulation. Nose and throat swabs taken from the experimenters failed to yield amoebae. The slit sampler used is difficult to sterilise and experiments were therefore done to show whether amoebae were introduced from there or were present in the cultures of Klebsiella. Twelve plates were prepared. Four were incubated without prior exposure, four were exposed in the slit sampler in a special room with a filtered air supply, and four were exposed as settle plates out of doors 
for $7 \mathrm{hr}$. No amoebae were found on the first two sets of plates, but the settle plates had 2, 2, 4 and 5 colonies of amoebae, thus showing that amoebae

TABLE I

Identification of amoebae isolated from air and their ability to grow in and produce a cytopathic effect in HeLa cells incubated at $33^{\circ} \mathrm{C}$ or $37^{\circ} \mathrm{C}$

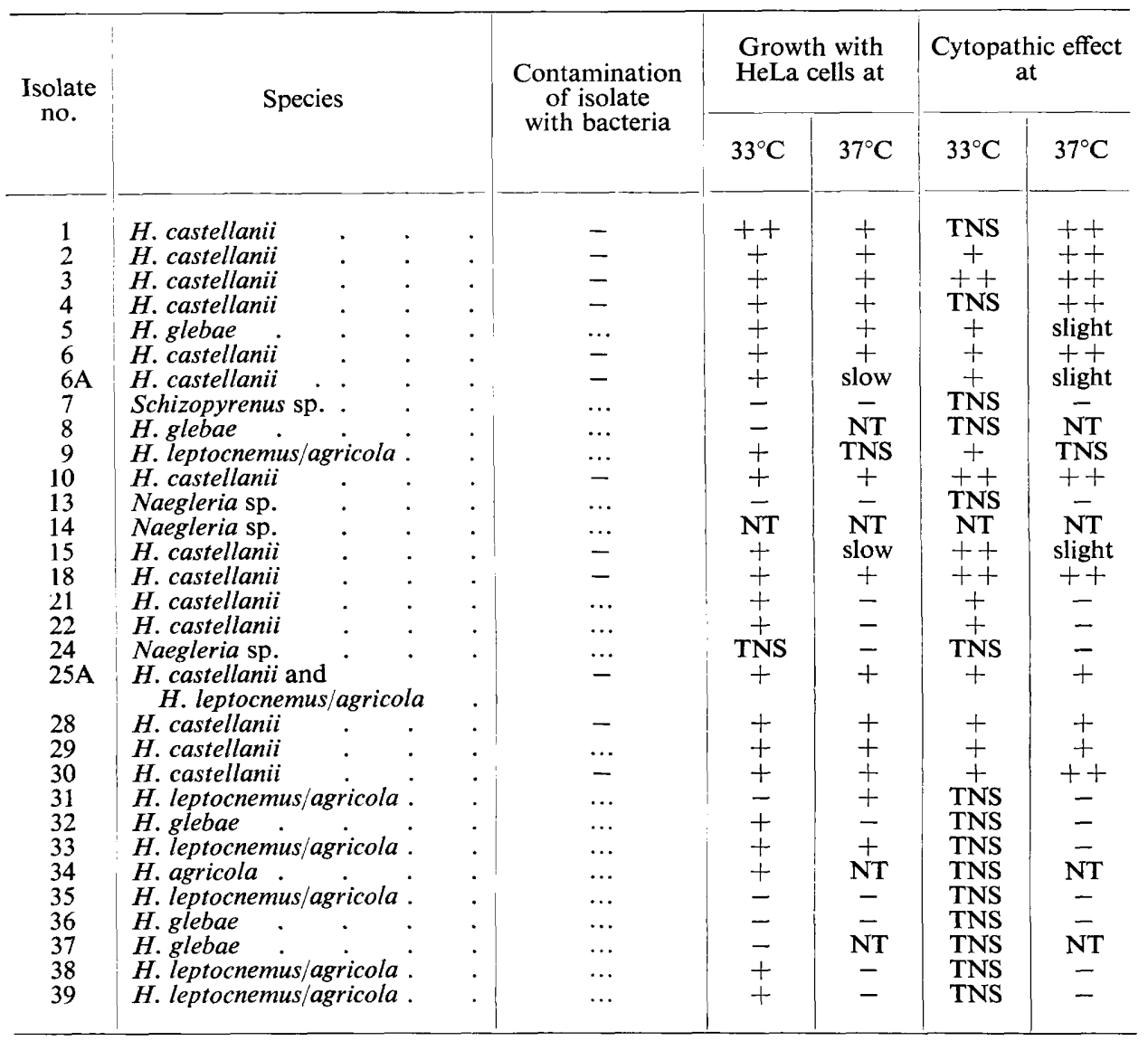

Isolations no. 1-3 were made on HeLa cells from specimens collected in a Manchester hospital. The other isolations were made on agar plates spread with Klebsiella aerogenes exposed in a slit sampler (4-25A) or as settle plates (28-39) in or outside a laboratory in London. Isolations 1-6A were made at $37^{\circ} \mathrm{C}$, the others at $30^{\circ} \mathrm{C}$ or $33^{\circ} \mathrm{C}$. Isolates no. $12,16,17$ and 20 , which did not grow on subculture, and no. 11, 18A, 19, 23, 25 and 26 and 27, which were not thought to be amoebae at the time of their isolation, have been omitted from the table.

NT $=$ No test. TNS $=$ Test not satisfactory. $+=$ Good growth, or definite cytopathic effect. $++=$ Vigorous growth, or very marked cytopathic effect. $-=$ No contamination with bacteria, no growth, or no cytopathic effect.

could be recovered by a technique not involving use of the slit sampler. In a repetition of this experiment six plates were exposed in each category, the settle plates being exposed in a specially ventilated experimental room on the second floor of the laboratory building. The unexposed controls were all 
negative for amoebae. Five of the settle plates showed a single colony of an amoeba and the sixth was negative. Of the slit-sampler controls, 4 out of 6 plates were negative, but the remaining two plates showed 12 and 13 amoebic colonies of identical appearance. These amoebae were not examined in detail. In a further attempt to recover amoebae by exposing plates in the room with a filtered air supply eight plates were exposed, half with the minimum of human presence and half with the experimenters moving and shaking clothes near the sampler. However, no further colonies could be recovered in this way and it was concluded that one of the polythene bags used to prevent the plates drying out during the prolonged incubation had become contaminated with amoebic cysts. In subsequent work it was made the rule always to discard the bags after one use.

\section{TABLE II}

Number of isolations of amoebae from indoor and outdoor air on klebsiella plates incubated at different temperatures

\begin{tabular}{|c|c|c|c|c|}
\hline \multirow{2}{*}{$\begin{array}{l}\text { Temperature } \\
\text { of incubation } \\
\text { of plates }\end{array}$} & \multicolumn{2}{|c|}{ Indoor air } & \multicolumn{2}{|c|}{ Outdoor air } \\
\hline & $\begin{array}{c}\text { number of plates } \\
\text { yielding amoebae/ } \\
\text { number of plates } \\
\text { exposed }\end{array}$ & $\begin{array}{l}\text { number of } \\
\text { isolations } \\
\text { of amoebae }\end{array}$ & $\begin{array}{c}\text { number of plates } \\
\text { yielding amoebae/ } \\
\text { number of plates } \\
\text { exposed }\end{array}$ & $\begin{array}{l}\text { number of } \\
\text { isolations } \\
\text { of amoebae }\end{array}$ \\
\hline $\begin{array}{l}37^{\circ} \mathrm{C} \\
\text { At or below } 33^{\circ} \mathrm{C}\end{array}$ & $\begin{array}{l}0 / 6 \\
2 / 3\end{array}$ & $\begin{array}{l}0 \\
3\end{array}$ & $\begin{array}{l}4 / 5 \\
9 / 11\end{array}$ & $\begin{array}{r}4 \\
14\end{array}$ \\
\hline All temperatures (total) & $2 / 9$ & $3 *$ & $13 / 16$ & $18 \dagger$ \\
\hline
\end{tabular}

* Volume of air yielding one cyst was, on average, $733 \mathrm{cu} . \mathrm{ft}\left(21 \mathrm{~m}^{3}\right)$.

+ Volume of air yielding one cyst was, on average, $322 \mathrm{cu} . \mathrm{ft}\left(9 \cdot 1 \mathrm{~m}^{3}\right)$.

\section{Characters of the amoebae}

The characters of the amoebae isolated from the air are summarised in table I. All the isolates thought to be amoebae were examined except those from the second batch of settle plates described in the previous section. A few isolates not thought to be amoebae were also examined and these together with four isolates that failed to grow on subculture have been omitted from table I. All but four of the isolates of $H$. castellanii damaged $\mathrm{HeLa}$ cells at $37^{\circ} \mathrm{C}$. Two isolates (no. 21 and 22) failed to grow at this temperature, but grew and damaged cells at $33^{\circ} \mathrm{C}$. Two strains (no. $6 \mathrm{~A}$ and 15 ) that grew poorly at $37^{\circ} \mathrm{C}$ were also poorly cytopathic at this temperature, but grew well and damaged $\mathrm{HeLa}$ cells at $33^{\circ} \mathrm{C}$. None of the other organisms had a cytopathic effect that could be distinguished from the normal necrosis of the cell sheet, except an isolate of $\mathrm{H}$. glebae (no. 5) which had a slight cytopathic effect at $37^{\circ} \mathrm{C}$ and a marked one at $33^{\circ} \mathrm{C}$, and an isolate of $H$. leptocnemus/agricola (no. 9) which had a cytopathic effect at $33^{\circ} \mathrm{C}$. 
In table II all the isolations of amoebae made by the agar plate method, including the four amoebae that failed to grow on subculture, are analysed to show the frequency of isolation under different conditions. In table III a similar analysis is made of the isolations of $H$. castellanii.

\section{Number and size of amoeba-carrying particles in air}

Since a colony of amoebae spreads fairly rapidly over a plate, once a colony has appeared incubation cannot be continued for much longer and multiple colonies on a plate may be missed. However, the high proportion of negative plates makes it unlikely that multiple colonies would have occurred frequently unless the amoebae were liberated in showers. It is interesting to compare the average volume of air in which a cyst is to be found, e.g., $322 \mathrm{cu}$. $\mathrm{ft}$ outdoors,

TABLE III

Number of isolations of Hartmannella castellanii from indoor and outdoor air on klebsiella plates incubated at different temperatures

\begin{tabular}{l|c|c|c}
\hline $\begin{array}{c}\text { Temperature } \\
\text { of incubation } \\
\text { of plates }\end{array}$ & $\begin{array}{c}\text { Indoor air } \\
\begin{array}{c}\text { number of plates } \\
\text { yielding amoebae/ } \\
\text { number of plates } \\
\text { exposed }\end{array}\end{array}$ & $\begin{array}{c}\text { number of plates } \\
\text { yielding amoebae/ } \\
\text { number of plates } \\
\text { exposed }\end{array}$ & $\begin{array}{c}\text { number of } \\
\text { isolations } \\
\text { of amoebae }\end{array}$ \\
\hline $37^{\circ} \mathrm{C}$ & $0 / 6$ & $3 / 6$ & 3 \\
At or below $33^{\circ} \mathrm{C}$ & $0 / 5$ & $6 / 14$ & 6 \\
\hline All temperatures (total) & $0 / 11$ & $9 / 20$ & $9 *$ \\
\hline
\end{tabular}

* Volume of air yielding one cyst was, on average, $644 \mathrm{cu} . \mathrm{ft}\left(18 \cdot 2 \mathrm{~m}^{3}\right)$.

with the volume of air breathed a day, i.e., $458 \mathrm{cu} . \mathrm{ft}\left(13 \mathrm{~m}^{3}\right)$ (calculated from $500 \mathrm{ml}$ per breath and 18 breaths per min.). Comparison of the rates of isolation in the slit sampler and by settle plates gives an indication of the size of the amoeba-carrying particles, since the number of particles of equivalent diameter (i.e., the diameter of a sphere of unit density that would behave aerodynamically in this way) settling on to $1 \mathrm{sq}$. $\mathrm{ft}\left(0.093 \mathrm{~m}^{2}\right)$ of horizontal surface in $1 \mathrm{~min}$. is approximately $0.006 \mathrm{Nd}^{2}$, where $\mathrm{N}$ is the number of particles in $1 \mathrm{cu}$. $\mathrm{ft}$ (28.3 litres) of air and $\mathrm{d}$ is the diameter of the particles in microns (Lidwell, 1948). Summing all the settle-plate results described under Experiments to exclude contamination gives 18 isolations on ten $5 \frac{1}{2}$ in. $(14 \mathrm{~cm})$ diameter plates exposed for $7 \mathrm{hr}$, or 0.026 amoebae per sq. ft $\left(0.28\right.$ per m $\left.\mathrm{m}^{2}\right)$ per min. One cyst in $322 \mathrm{cu} . \mathrm{ft}\left(9 \cdot 1 \mathrm{~m}^{3}\right)$ of air passing through the slit sampler corresponds to 0.0031 per cu. $\mathrm{ft}\left(0 \cdot 11 \mathrm{per} \mathrm{m}^{3}\right)$ and this gives $\mathrm{d}=37 \mu \mathrm{m}$. The corresponding figures for $H$. castellanii are three isolations on four plates, or 0.011 amoebae per sq. $\mathrm{ft}\left(0.12\right.$ per $\left.\mathrm{m}^{2}\right)$ per min. and 0.0016 cysts per $\mathrm{cu} . \mathrm{ft}$ $\left(0.056\right.$ per $\left.\mathrm{m}^{3}\right)$. These values give $\mathrm{d}=33 \mu \mathrm{m}$. The microscopically measured 
diameters of $H$. castellanii, $H$. glebae and Naegleria cysts lie in the range 12-31 $\mu \mathrm{m}$ and those of the smaller amoebae, $H$. agricola and $H$. leptocnemus, lie in the range $10-20 \mu \mathrm{m}$. The high values found for the particle diameters $(33$ and $37 \mu \mathrm{m})$ from the settle plate counts probably only reflect the low accuracy resulting from the small numbers and the fact that the samples were not taken at the same time, but they could indicate that the cysts were associated with particles of soil. Airborne particles in this size range will be impacted in the nose (Druett, 1967).

\section{DISCUSSION}

Since the amoebae discussed in this paper are free-living soil organisms, the occurrence of their resistant cysts in the air is not surprising. The observed rate of their settling $\left(0.026\right.$ amoebae per sq. $\mathrm{ft}$, or 0.28 per $\mathrm{m}^{2}$ per min.) does not suggest that chance contamination by settling would occur frequently during laboratory manipulation.

The possible medical importance of the presence of cysts in the air depends on whether infections can be initiated by the cystic stage and whether some or all strains of some or all species are pathogenic. Histological studies have incriminated small free-living amoebae as the cause of meningitis and brain abscesses (Fowler and Carter, 1965; Callicott, 1968; Črva and Novák, 1968). Amoebae were isolated from two fatal cases of meningoencephalitis by Butt (1966) and Dr C. G. Culbertson told us that one of these strains was shown to be a schizopyrenid that was pathogenic to mice and monkeys. Culbertson et al. (1959) found that a hartmannellid amoeba was pathogenic to mice on intranasal or intracerebral inoculation, and was pathogenic to cortisone-treated rhesus monkeys on intravenous inoculation, but only when very large doses were used. Culbertson (1961) similarly found that the amoeba was pathogenic on intranasal instillation into cortisone-treated monkeys. Červa (1967a and $b$ ) in an important series of studies with Culbertson's strain of Hartmannella castellanii found that when it was inoculated from actively growing cultures it was highly pathogenic, single amoebae being capable of causing death in mice, rats and guinea-pigs. He also found that a strain of $H$. castellanii isolated from soil by Neff (1957) was not pathogenic.

It seems very probable, therefore, that some but not all strains of free-living amoebae can cause fatal infections, mainly cerebral abscesses. The rapid and peculiar cytopathic effect produced by " Ryan virus " (Armstrong and Pereira, 1967) reinforces the idea that these organisms are potentially pathogenic to mammalian cells. However, many of the fatal human infections have been associated with swimming in contaminated water, which presumptively contained the trophozoites, and trophozoites have been used in all the animal studies reported. Thus there is no direct evidence of the pathogenicity of the cysts, and Cerva's work tends to suggest that these are likely to be less pathogenic than the trophozoites. However, the presence of cysts in the air provides a simple explanation of the occurrence of amoebae in the upper respiratory tract (Wang and Feldman, 1967). For amoebae to become established it is presumably necessary that the cyst should be retained long enough in a suitable 
area for excystment to occur and for the trophozoites to proliferate before they are eliminated. Brain infections might follow if the amoebae were then able to penetrate the cribriform plate.

In considering possible pathogenicity, the maximum temperature of growth is important. Amoebae that cannot grow at $37^{\circ} \mathrm{C}$ are unlikely to be able to infect the brain, but if they are able to grow at about $33^{\circ} \mathrm{C}$ (Negus, 1958) they may be able to grow in and damage the upper respiratory tract. " Ryan virus" as originally described (Pereira et al., 1966) was thought to be associated with respiratory tract infections, and Eldridge and Tobin (1967) found complementfixing antibodies in patients from whose throats amoebae had been isolated. It is therefore significant that some of the strains here classified as $H$. castellanii were unable to grow at $37^{\circ} \mathrm{C}$, suggesting possibly that the maximum temperature of growth should be determined, as well as the taxonomic position of the isolate. However, it is possible that this temperature would be affected by the conditions of culture.

\section{SUMMARY}

In preliminary studies in a hospital in Manchester in which tissue culture was used for cultivation, Hartmannella castellanii was isolated from the air on two occasions and from surface samples on one. Water agar plates with a lawn of Klebsiella aerogenes were exposed in a slit sampler, or as settle plates, in and outside a laboratory in London and the following amoebae were isolated: 12 strains of $H$. castellanii, 7 of $H$. leptocnemus/agricola, 5 of $H$. glebae, 1 of $H$. agricola, 3 of Naegleria sp. and 1 of Schizopyrenus sp. In outdoor air an average of one amoebic cyst of any species was found in $322 \mathrm{cu}$. $\mathrm{ft}\left(9 \cdot 1 \mathrm{~m}^{3}\right)$ and one cyst of $H$. castellanii in $644 \mathrm{cu}$. $\mathrm{ft}\left(18.2 \mathrm{~m}^{3}\right)$. All the isolates of $H$. castellanii damaged HeLa cells. Four that grew poorly or not at all at $37^{\circ} \mathrm{C}$ showed a marked cytopathic effect at $33^{\circ} \mathrm{C}$. An identification key is given.

We are grateful to our colleagues for helpful comments on the manuscript and to Mr R. O. Folwell and Mr D. Samson for invaluable technical assistance.

\section{REFERENCES}

Adam, Katherine M. G. . . . . . 1964. J. Protozool., 11, 423.

Armstrong, J. A., And Pereira, Mar- 1967. Br. Med. J., 1, 212. GUERITE $S$.

Bunting, Martha . . . . . . . 1926. J. Morph., 42, 23.

Butt, C. G. . . . . . . . . 1966. New Engl. J. Med., 274, 1473.

Callicott, J. H., JR . . . 1968. Amer. J. Clin. Path., 49, 84.

Červa, L. . . . . . . . . . 1967a. Folia parasit., Praha, 14, 171.

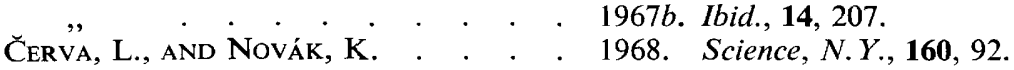

Culbertson, C. G. - . . . . . . 1961. Amer. J. Clin. Path., 35, 195.

Culbertson, C. G., Smith, J. W., Cohen, 1959. Amer. J. Path., 35, 185.

H. K., AND MinNER, J. R.

Dobell, C. . . . . . . . . . . 1914. Arch. Protistenk., 34, 139.

Douglas, M. . . . . . . . . 1930. J. Trop. Med. Hyg., 33, 258.

DruetT, H. A. . . . . . . . . 1967. In Airborne microbes, XVII Symposium of the Society for General Microbiology, Cambridge, p. 165. 
Eldridge, A. E., ANd Tobin, J. O'H. 1967. Br. Med. J., 1, 299.

Fowler, M., AND CARTER, R. F. . . 1965. Ibid., 2, 740.

Goodey, T. . . . . . . . . . 1916. Proc. Zool. Soc. Lond., 21, 309.

Kingston, D. . . . . . . . . 1969. J. Appl. Bact., 31, 498.

Kudo, R. R. . . . . . . . . . 1954. Protozoology, 4th ed., Springfield, Ill.

Lidwell, O. M. . . . . . . . 1948. In Studies in air hygiene, Spec. Rep. Ser. Med. Res. Coun., 262, 320.

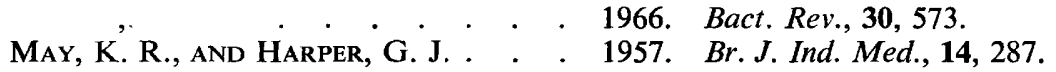

NefF, R. J. . . . . . . . . . 1957. J. Protozool., 4, 176.

Negus, V. . . . . . . . . . 1958. The comparative anatomy and physiology of the nose and para-nasal sinuses,

Page, F. C. 1967. J. Protozool., 14, 709.

Pereira, Marguerite S., Marsden, 1966. Br. Med.J., 1, 130.

H. B., CORBITt, G., AND TOBIN, J. O'H. Perty, J. A. M.

1852. Zur Kenntniss kleinster Lebensformen nach Bau, Funktionen, Systematik, mit Specialverzeichniss der in der Schweiz beobachten, Bern, p. 170.

Ray, D. L., AND Hayes, R. E. . . . 1954. J. Morph., 95, 159.

Schardinger, F. . . . . . . . 1899. Sber. Akad. Wiss. Wien., 108, 713.

Singh, B. N. . . . . . . . . 1952. Phil. Trans. Roy. Soc. B, 236, 405.

VolKonsky, M. . . . . . . . 1931. Archs Zool. exp. gén., 72, 317.

Wang, S. S., And Feldman, H. A. . . 1967. New Engl. J. Med., 277, 1174.

Warhurst, D. C., AND Armstrong, J. A. 1968. J. Gen. Microbiol., 50, 207. 